\title{
Tingkat Pengetahuan Perawat dan Pelayanan Syariah dalam Bidang Keperawatan di Rumah Sakit Islam Sultan Agung Semarang
}

\author{
Galuh Adityani $^{(\mathrm{CA})}$, Muh Abdurrouf ${ }^{2}$, Dyah Wiji Puspita Sari ${ }^{3}$ \\ ${ }^{1(\mathrm{CA})}$ Program Studi S1 Keperawatan, Fakultas Ilmu Keperawatan, Universitas Islam Sultan Agung \\ Semarang, galuhadityani11@gmail.com (Corresponding Author) \\ ${ }^{2}$ Program Studi S1 Keperawatan, Fakultas Ilmu Keperawatan, Universitas Islam Sultan Agung Semarang, \\ muh.abdurrouf@gmail.com \\ ${ }^{3}$ Program Studi S1 Keperawatan, Fakultas Ilmu Keperawatan, Universitas Islam Sultan Agung Semarang, \\ daiyah_04@yahoo.com
}

\begin{abstract}
Islamic services on nursing is the nursing services performed by nurses based on the quran and the hadist, which include indicators of the minimum service standard and quality indicators of compulsory shariah, between other reading basmalah in administering drugs and action, the hijab for patients, the ECG installation of appropriate gender, reminiscent of the time of prayer, the DC installation of appropriate gender. From the characteristics of respondents in this study with 104 respondents $37.5 \%$ of respondents aged 36-45 years, $67.3 \%$ of respondents were female, $58.7 \%$ of respondents had elementary school education. This study shows data that there is a significant relationship between nurses caring behavior with patient loyalty in the great sultan Agung Islamic hospital with p-value 0,000 or p-value $<0.05$ and for close relationship classified as low (0.397) and direction of a positive relationship. Based on the results of research nurses are expected to further enhance good caring behavi or to improve the quality of hospital services.
\end{abstract}

Keywords: Islamic services on nursing, level knowledge

\begin{abstract}
ABSTRAK
Bentuk pelayaanan yang berdasarkan standart minimal pelayanan RS Syariah yang meliputi pemasangan hijab untuk pasien, pemasangan EKG dan kateter sesuai gender, hijab untuk ibu menyusui dimana pelayanan yang sesuai dengan harapan klien. Penelitian ini menggunakan jenis penelitian kuantitatif dengan pendekatan cross sectional. Pengumpulan data menggunakan kuesioner dengan jumlah responden sebanyak 96. Penelitian ini menggunakan teknik simple random sampling dan diolah secara statistik dengan menggunakan korelasi spearmen. Berdasarkan hasil analisis yang diperoleh dari 96 responden $40,6 \%$ responden berumur $26-35$ tahun, $66,7 \%$ responden berjenis kelamin perempuan, $62,5 \%$ responden berstatus sudah menikah, 60,4\% responden pendidikan terakhir DIII, dan 56,3\% responden lama kerja 1-5 tahun. Penelitian ini menunjukkan data bahwa terdapat Ada hubungan tingkat pengetahuan perawat dengan pelayanan syariah dalam bidang keperawatan di RSISA Semarang nilai p value 0,000 ( $p$ value $<0,05$ dan keeratan hubungan yaitu kuat $(0,711)$ serta arah hubungannya positif
\end{abstract}

Kata Kunci : Pelayanan Syariah Dalam Bidang Keperawatan, Tingkat Pengetahuan

\section{PENDAHULUAN}

Kurangnya tingkat pengetahuan perawat tentang pelaksanaan pelayanan Syariah dapat memberikan dampak yang negatif terhadap perawat maupun pasien. Hal ini dapat menyebabkan pelayanan yang diterima kurang bermutu karena pelayanan yang diperoleh kurang sesuai dengan yang diharapkan oleh pasien sesuai dengan standar yang ditentukan oleh Rumah Sakit berbasis Syariah. 
Kurangnya pengetahuan perawat tentang pelaksanaan Syariah dapat menyebabkan ketidakpuasaan bagi pasien maupun pelanggan (Syakuro, $2010 \&$ Wulandari, 2015).

Penurunan jumlah kunjungan pasien rawat inap di RSUD Kabupaten Buton dari tahun 2012-2015 menurun sehingga saat ini menajemen sedang mencari penyebab yang mempengaruhi penurunan jumlah pasien. Adapun faktor yang berpengaruh pada pelayanan RSUD Kabupaten Buton yaitu kualitas pelayanan, kepuasan pasien, nilai pasien dan citra rumah sakit setelah menerima pelayanan dari RSUD Kabupaten Buton (Rif'adarajad, 2016).

Pelayanan kesehatan harus mulai meningkatkan kualitas pelayanannya dengan berjalannya waktu. Apalagi hal ini berbanding lurus dengan semakin selektifnya masyarakat memilih pelayanan rumah sakit yang dipilih. Informasi yang beredar dengan bebas dari berbagai media, masyarakat menjadi mempunyai banyak pengetahuan terutama kualitas dan mutu dari suatu pelayanan dalam masyarakat, terutama dalam bidang pelayanan kesehatan itu sendiri. Peningkatan kualitas pelayanan dapat dilakukan setelah diketahuinya apakah suatu pelayanan tersebut telah mencapai harapan pasien atau belum (Syakuro, 2010).

Pelayanan Syariah di bidang keperawatan merupakan salah satu bentuk pelayanan kesehatan dimana perawat berperan penting dalam memberikan pelayanan kepada semua pasien dan memiliki tanggung jawab untuk memberikan pelayanan sesuai dengan standar yang ditentukan oleh Rumah Sakit yang berbasis Syariah (Syakuro, 2010 \& Wulandari, 2015).

Hasil studi pendahuluan dilakukan oleh peneliti pada bulan Agustus 2019 di RSISA Semarang melalui metode wawancara 10 perawat di ruang bangsal Baitussalam 1 dan Baituizzah 1, diperoleh hasil 6 (60\%) tingkat pengetahuan perawat baik dan 4 (40\%) tingkat pengetahuan perawat cukup. Berdasarkan melalui metode kuesioner didapatkan pula data bahwa $5(50 \%)$ perawat selalu melalukan pelayanan syariah terhadap pasien, 3 (30\%) perawat sering melakukan pelayanan syariah terhadap pasien, sedangkan 2 (20\%) perawat jarang melakukan pelayanan syariah terhadap pasien.

\section{METODE}

Jenis penelitian yang digunakan yaitu penelitian kuantitatif dengan menggunakan desain penelitian deskriptif korelasional yaitu dengan mencari hubungan antara variabel bebas (tingkat pengetahuan perawat) dengan variabel terikat (pelayanan syariah dalam bidang keperawatan). Penelitian ini menggunakan pendekatan cross sectional (potong lintang), Studi cross sectional adalah pengumpulan data penelitian yang dilakukan sekaligus pada waktu yang sama (Notoatmojo, 2010). Populasi merupakan seluruh objek atau seluruh subjek yang telah memiliki kualitas dan karakteristik tertentu yang sudah ditentukan oleh peneliti untuk diteliti (Santjaka, 2011). Populasi penelitian yaitu pasien yang ada di ruang rawat inap Baitussalam 1 dan 2, Baitunnisa 1 dan 2, Baitulizzah 1 dan 2, Baitul Rijjal di RSISA Semarang yaitu sebanyak 126 responden.

Penelitian ini menggunakan instrumen dalam bentuk kuesioner dengan menyertakan checklist kuesioner yang berisi pertanyaan. Kuesioner pelaksana indikator mutu wajib dan standar pelayanan menggunakan cheklist yang terdiri sebanyak 36 pernyataan dan Kuesioner tingkat pengetahuan terdapat 14 pernyataan. 


\section{HASIL DAN PEMBAHASAN}

\section{A. Karakteristik Subjek Penelitian}

1. Karakteristik Subjek Penelitian Berdasarkan Umur.

Tabel 1 Distribusi Frekuensi Subjek Penelitian Umur Responden di RSISA Semarang (n=96).

\begin{tabular}{lcc}
\hline Umur & n & \% \\
\hline $17-25$ tahun & 36 & 40,6 \\
$26-35$ tahun & 54 & 56,3 \\
$36-45$ tahun & 3 & 3,1 \\
\hline
\end{tabular}

Tabel 1 menunjukkan hasil penelitian bahwa responden yang tertinggi yaitu umur 26-35 tahun berjumlah 54 orang dengan prosentase $(56,3 \%)$ dan yang terrendah umur 36-45 tahun berjumlah 3 orang dengan prosentase $(3,1 \%)$.

Penelitian dari Wijayanti (2008) menyatakan bahwa umur dibawah 30 tahun merupakan fase seseorang untuk memulai berkomitmen dengan masa depannya, dan berusaha bekerja dengan baik agar mendapatkan karir yang memuaskan. Berdasarkan penelitian sebelumnya menurut Trisnantoro (2006) dalam Desimawati (2013), bahwa setiap individu mempunyai kebutuhan dalam menerima pengetahuan berdasarkan bertambahnya usia, tuntutan suatu pengetahuan semakin meningkat seiring bertambahnya usia.

Hal ini seiring dengan pendapat yang dinyatakan oleh Umar (2001) dalam Oroh, Rompas, \& Pondaag (2014) yang mengatakan apabila usia semakin bertambah kemampuan fisiologis ikut menurun, dan biasanya dimulai dari umur 30 - 45 tahun. Pada usia yang sama pula terjadi penurunan kemampuan emosional sebesar $1 \%$ per tahun, hal ini membuat penurunan indeks pengetahuan kurang lebih sebesar $40 \%$.

\section{Karakteristik Subjek Penelitian Berdasarkan Pernikahan}

Tabel 2 Distribusi Frekuensi Subjek Penelitian Pernikahan Responden di RSISA Semarang $(n=96)$

\begin{tabular}{lcc}
\hline Pernikahan & n & \% \\
\hline Sudah menikah & 60 & 62,5 \\
Belum menikah & 36 & 37,5 \\
\hline
\end{tabular}

Tabel 2 hasil penelitian bahwa responden terbanyak dengan responden yang sudsh menikah berjumlah 60 orang dengan presentase (62,5\%). Pendapat Trisnantoro (2006) tentang status pernikahan yang berkaitan dengan tingkat pengetahuan seseorang, bahwa seseorang yang sudah menikah mempunyai faktor emosional yang lebih tinggi dibanding dengan seseorang dengan status belum menikah. Hal ini disebabkan orang yang sudah menikah akan diberikan saran oleh pasangannya dalam mempelajari pengetahuan tentang pelayanan kesehatan yang sesuai dengan harapannya yang berbasis syariah. 
Pada penelitian yang dilakukan Kurniawan \& Intisari (2012) didapatkan hasil bahwa status pernikahan menunjukkan pengaruhnya terhadap tingkat pengetahuan terhadap pelayanan syariah. Dia juga menyatakan bahwa tingkat pengetahuan perawat menunjukkan bersifat subjektif, subjektif adalah penilaian perasaan yang dinilai oleh seseorang namun akan berbeda hasil dari masing - masing individu tersebut. (Kurniawan \& Intisari, 2012).

\section{Karakteristik Subjek Penelitian Berdasarkan Pendidikan Terakhir}

Tabel 3 Distribusi Frekuensi Subjek Penelitian Pendidikan Terakhir Responden di RSISA Semarang $(n=96)$.

\begin{tabular}{lcc}
\hline Pendidikan Terakhir & n & \% \\
\hline DIII & 58 & 60,4 \\
S1 & 38 & 39,6 \\
\hline
\end{tabular}

Tabel 3 menunjukkan bahwa responden terbayak dengan pendidikan terakhir DIII sebanyak 58 orang dengan prosentase (60,4\%). Menurut Ritonga (2017) pendidikan merupkan usaha individu dalam menegembangkan kemampuan yg berlangsung, pendidikan mempengaruhi proses belajar semakin tinggi pendidikan seseorang maka semakin mudah orang untuk menerima informasi baik dari orang lain maupun dari media massa.

Penelitian Suparna (2015) perawat dengan pendidikan DIII keperawatan yang cukup baik akan melakukan praktik keperawatan yang efektif dan efesien dan menghasilkan pelayanan yang bermutu tinggi, dimana tingkat pendidikan perawat akan mempengaruhi dasar pemikiran dibalik penerapan standart keperawatan.

Pada teori sebelumnya yang dikemukakan oleh Lumenta (1989) bahwa semakin tinggi tingkat pendidikan seseorang, maka akan semakin banyak tuntutan dan harapan mereka terhadap suatu pelayanan terutama pada pelayanan kesehatan. Sedangkan menurut Barata (2006) seseorang yang berpendidkan rendah tidak pernah ataupun jarang berpikir diluar daya nalarnya, misalnya tidak memberikan perhatian khusus terhadap suatu pelayanan terutama pada pelayanan kesehatan tersebut (Budiman, Suhat, \& Herlina, 2010).

\section{Tingkat Pengetahuan Perawat}

Tabel 4 Distribusi Frekuensi Subjek Penelitian Tingkat Pengetahuan Responden di RSISA Semarang $(\mathrm{N}=96)$.

\begin{tabular}{lcc}
\hline Tingkat Pengetahuan & $\mathbf{n}$ & $\%$ \\
\hline Baik & 63 & 65,6 \\
Cukup & 19 & 19,5 \\
Kurang & 14 & 14,6 \\
\hline
\end{tabular}


Tabel 4 menunjukkan hasil penelitian bahwa responden terbanyak tingkat pengetahuan perawat tertinggi dengan kategori baik dengan jumlah 63 responden dengan persentase $(65.6 \%)$, dan terrendah dengan kategori kurang terdapat 14 responden dengan presentase $(14.6 \%)$.

Teori penelitian sebelumnya yang dilakukan oleh Anggono (1996) dalam Suryati,dkk (2006) bahwa tingkat pengetahuan perawat dipengaruhi oleh ketrampilan perawat dalam pemberian pelayanan kesehatan. Hal ini sejalan dengan Kotler (2005) dalam Sangadji dan Sopiah (2013) bahwa tingkat pengetahuan perawat dapat dihitung menggunakan perhitungan seberapa besar harapan pasien tentang pelayanan yang diberikan pemberi layanan (perawat) secara aktual.

Perbandingan antara hasil studi pendahuluan dan penelitian ini dapat dilihat dari presentasi tingkat pengetahuan perawat. Pada studi pendahuluan didapatkan hasil tingkat kepuasan pasien adalah $60 \%$ yang menyatakan tingkat pengetahuan perawat baik, sedangkan pada penelitian ini pengetahuan perawat dalam penelitian mayoritas menyatakan baik atau paham dari 96 responden. Hasil dari penelitian ini didukung oleh beberapa aspek. Aspek utama adalah pada pelayanan syariah dalam bidang keperawaatan yang diberikan oleh RSISA Semarang. Semakin baik pelayanan rumah sakit yang diterima maka semakin baik juga tingkat pengetahuan perawat yang dipahami.

\section{Pelayanan Syariah}

Tabel 5 Distribusi Frekuensi Subjek Penelitian Pelayanan Syariah di RSISA Semarang $(\mathrm{N}=96)$.

\begin{tabular}{lcc}
\hline Pelayanan Syariah & n & $\%$ \\
\hline Baik & 84 & 87,5 \\
Cukup & 5 & 5,2 \\
Kurang & 7 & 7,3 \\
\hline
\end{tabular}

Tabel 5 menunjukkan hasil penelitian bahwa pelayanan syariah tertinggi dengan kategori baik berjumlah 84 responden dengan persentase $(87.5 \%)$, dan terrendah terdapat 5 orang dengan persentase $(5.2 \%)$ memiliki pelayanan syariah cukup.

Pelayanan keperawatan menurut Walgito (dalam Sunaryo, 2004), yaitu suatu pelayanan yang diterima oleh pasien dan pasien tersebut mampu memberikan persepsinya yang merupakan interpretasi dari rangsangan yang telah pasien itu terima (Desimawati 2013).

Pada penelitian sebelumnya yang dilakukan oleh Hafid (2016) dimana sebuah rumah sakit (RS Ibnu Sina) membangun citra rumah sakit dan membentuk loyalitas pasien terhadap RS Ibnu Sina dengan menggunakan indikator - indikator pelayanan dengan prinsip syariah dalam pemberian perhatian pelayanan kesehatan.

\section{B. Hubungan Antara Tingkat Pengetahuan Perawat Dengan Pelayanan Syariah Dalam Bidang Keperawatan}


Tabel 6 Uji Spearment Hubungan Antara Tingkat Pengetahuan Perawat Dengan Pelayanan Syariah Dalam Bidang Keperawatan di RSISA Semarang (N=96).

\begin{tabular}{|c|c|c|c|c|c|c|c|c|}
\hline \multirow{3}{*}{ Tingkat pengetahuan } & \multicolumn{6}{|c|}{ Pelayanan Syariah } & \multirow{2}{*}{\multicolumn{2}{|c|}{ Total }} \\
\hline & \multicolumn{2}{|c|}{ Baik } & \multicolumn{2}{|c|}{ Cukup } & \multicolumn{2}{|c|}{ Kurang } & & \\
\hline & $\mathbf{n}$ & $\%$ & $\mathbf{n}$ & $\%$ & $\mathbf{n}$ & $\%$ & $\mathbf{n}$ & $\%$ \\
\hline Baik & 62 & 98,4 & 1 & 1,6 & 0 & 0,0 & 63 & 100 \\
\hline Cukup & 15 & 78,9 & 3 & 15,8 & 1 & 5,3 & 19 & 100 \\
\hline Kurang & 7 & 50,0 & 1 & 7,10 & 6 & 42,9 & 14 & 100 \\
\hline Total & 48 & 87,5 & 5 & 5,2 & 7 & 7,3 & 96 & 100 \\
\hline \multicolumn{9}{|c|}{$P$-value $=0,000$} \\
\hline \multicolumn{9}{|c|}{$\mathrm{R}=0,711$} \\
\hline
\end{tabular}

Tabel 6 menunjukkan hasil penelitian bahwa didapatkan data terdapat hubungan yang bermakna antar tingkat pengetahuan perawat dengan pelayanan syariah dalam bidang keperawatan di RSISA Semarang dengan melihat hasil nilai dari $p$ value sig. (2-tailed) yaitu 0,000 atau $p$ value $<0,05$. Penelitian sebelumnya oleh Sri (2015) diperoleh hasil bahwa Secara koefisien determinan variabel pelayanan dengan prinsip syari'ah menjelaskan variabel tingkat pengetahuan perawat di RSI Kendal, yaitu sebesar 0,30 atau 30\%. Secara simultan variabel pelayanan dengan prinsip syari'ah berpengaruh positif terhadap tingkat pengetahuan perawat di RSI kendal, nilai probabilitas sebesar 0,000. Jika tingkat pengetahuan perawat semakin naik, maka pelayanan dengan prinsip syari'ah juga semakin naik.

Hasil penelitian ini sesuai dengan pendapat Yuanita saiful dan setya wibawa (2014), dimana aspek pertama yang harus diperhatikan dalam memberikan pelayanan syariah adalah peningkatan pengetahuan perawat tentang pelayanan syariah dan manfaatnya kepada klien, sebab sikap positif atau negatif seseorang terhadap suatu obyek, sangat ditentukan oleh tingkat pengetahuan seseorang terhadap manfaat pada obyek tersebut. Jadi semakin tinggi tingkat pengetahuan perawat tentang pelayanan syariah maka semakin baik pula dalam pemenuhan memberikan pelayanan syariah kepada klien.

Hasil penelitian Hubungan tingkat pengetahuan perawat dengan pelayanan syariah dalam bidang keperawatan didapatkan hasil tingkat pengetahuan perawat dengan kategori baik yang menunjukkan pelayanan syariah baik sebanyak 62 responden $(98,4 \%)$, menunjukkan pelayanan syariah cukup 1 responden $(1,6 \%)$ dan yang menunjukkan pelayanan syariah kurang 0 responden $(0,0 \%)$. Pada tingkat pengetahuan perawat dengan kategori cukup yang menunjukkan pelayanan syariah baik sebanyak 15 responden (78,9\%), menunjukkan pelayanan syariah cukup 3 responden $(15,8 \%)$ dan yang menunjukkan pelayanan syariah kurang sebanyak 1 responden $(5,3 \%)$. Sedangkan tingkat pengetahuan perawat dengan kategori kurang yang menunjukkan pelayanan syariah baik sebanyak 7 responden (50,3\%), yang menunjukkan pelayanan syariah cukup sebanyak 1 responden $(7,1 \%)$ dan yang menunjukkan pelayanan syariah kurang sebanyak 6 responden $(42,9 \%)$. 


\section{KESIMPULAN}

Responden yang menyatakan tentang pelayanan syariah di bidang keperawatan sebagian besar dengankategori baik. Responden yang menyatakan tingkat pengetahuan perawat sebagian besar dengan kategori baik. Adanya hubungan tingkat pengetahuan perawat dengan pelayanan syariah dalam bidang keperawatan di RSISA Semarang.

\section{UCAPAN TERIMAKASIH}

Saya ucapkan terimakasih kepada Bapak Ns. Muh. Abdurrouf, M. Kep selaku pembimbing I dan ibu Ns. Dyah Wiji Puspita Sari, M. Kep selaku pembimbing II yang telah sabar dan meluangkan waktu serta tenaga dalam memberikan ilmu dan nasehat yang bermanfaat dengan penuh perhatian, kelembutan, dan selalu memberikan memotivasi. Kedua orangtua saya yang saya hormati Bapak Lilik Supriyanto dan Ibu saya yang saya sangat cintai Ibu Mujiyanti. Serta teman teman saya yang tidak bosan-bosannya memberi saya dukungan dan senyuman serta mau mendengar keluh kesah saya.

\section{DAFTAR PUSTAKA}

Agus Riyanto, (2011). Aplikasi Metodologi Penelitian Kesehatan. Nuha. Medika Yogyakarta.

Amir, Taufik. (2015). Inovasi Pendidikan Melalui Problem Based Learning: Bagaimana Pendidik Memberdayakan Pemelajar di Era Pengetahuan. Jakarta:Kencana.

Bakar, A., \& Kurniawati, N. D. (2013). Studi Fenomenologi Pengalaman Ibadah Pasien Islam Yang Di Rawat Dengan Pendekatan Spiritual islam Di Rumah Sakit Asyiah Bojonegoro Dan Rumah Sakit Haji Surabaya. Surabaya: UniversitasAirlangga.

Budiman, Suhat A, Herlina. (2010). Buku Ajar Penelitian Kesehatan Jilid Ke-1. Cimahi: Stikes Ahmad Yani.

Chandra, B. (2008). Metodologi Penelitian Kesehatan. Jakarta: EGC.

Dahlan, S.M. 2013. Besar Sampel dan Cara Pengambilan Sampel. Jakarta: Salemba Medika.

Depkes RI, 2009. Sistem Kesehatan Nasional. Jakarta

Easter, T. C., Wowor, M., \& Pondaag, L. (2017, Februari). Hubungan Pelayanan Keperawatan Dengan Kepuasan Pasien BPJS Rawat Inap Di Ruang Hana RSU Pancaran Kasih GMIM Manado. EJournal Keperawatan (e-Kp) Volume 5, No. 1

Husein Umar. (2001). Metode Penelitian dan Aplikasi dalam Pemasaran. Jakarta:PTGramedia Pustaka Umum

Joewono, B. S. \& Prabowo, P. (2013). Ilmu Penyakit Jantung. Surabaya: Airlangga University Press.

Kotler, Philip. 2005. Managemen Pengetahuan Perawat, Jilid 1 dan 2. Jakarta: PT. Indeks Kelompok Gramedia.

Kurniawan, A., \& Intisari, A. D. (2012).Pengaruh Karakteristik Pasien Terhadap Indeks Kepuasan Masyarakat Tentang Pelayanan Rawat Jalan Puskesmas Banyumas. Jurnal Kesmasindo, Volume 5 Nomor 2 Hal. 169-179.

Lumenta, Benjamin. 1989. Pelayanan Medis Citra, Konflik dan Harapan.Penerbit Kanisius. Yogyakarta. 
Meliono, Irmayanti, editors. Pengetahuan [monograph on the Internet]. Jakarta: Lembaga Penerbitan FEUI; 2007 [cited 2009 Jun 10]. Available from: http://id.wikipedia.org/wiki/Pengetahuan.

MUI, D., \& MUKISI. (2017). Standar \& Instrumen Sertifikasi Rumah Sakit Syariah . Jakarta: MUKISI.

MUI, Himpunan Keputusan Musyawarah Nasional VII Majelis Ulama Indonesia, Jakarta: Sekretariat MUI, 2005.

Notoatmodjo S. 2012. Promosi Kesehatan dan Perilaku Kesehatan. Jakarta: PT Rineka Cipta.

Notoatmodjo S. Promosi Kesehatan dan Ilmu Perilaku. Jakarta: PT Rineka Cipta; 2007

Notoatmodjo, S. (2010). Metodologi Penelitian Kesehatan. Jakarta: Rineka Cipta. Notoatmodjo, Soekidjo. 2003. Pendidikan Dan Perilaku Kesehatan. Rineka Cipta. Jakarta.

Nursalam. (2013). Pendekatan Praktis Metodologi Penelitian Ilmu Keperawatan Edisi 3. Jakarta: Salemba Medika.

Potter, P \& Perry, A. (2005). Buku Ajar Fundamental Keperawatan : Konsep, Proses dan Praktik. Edisi 4. Jakarata : EGC.

Santjaka, A. (2011). Statistik Untuk Penelitian Kesehatan (Deskriptif, Parametrik Dan Non Parametrik). Yogyakarta: Nuha Medika.

Saryono.(2010). Metodologi Penelitian Kesehatan Penuntun Praktis Bagi Pemula. Yogyakarta: Mitra Cendek

Sugiyono. (2011). Metode Penelitian Kuantitatif Kualitatif dan $R \& D$. Bandung: Alfabeta.

Sugiyono. (2014). Metode Penelitian Pendidikan Pendekatan Kuantitatif,Kualitatif, dan R\&D. Bandung: Alfabeta.

Sulistiadi, W., \& Rahayu, S. (2016). Potensi Penerapan Maqashid Syariah Dalam Rumah Sakit Syariah Di Indonesia. Jakarta: Universitas Indonesia. 